\title{
Molecular evidence confirms presence of anamorph of Erysiphe diffusa on soybean (Glycine max) in northeast India
}

\author{
Pankaj Baiswar $^{1} \cdot$ Satish Chandra ${ }^{1} \cdot$ Shishomvanao Ngachan ${ }^{1}$
}

Received: 13 October 2015 / Accepted: 27 July 2016 /Published online: 3 August 2016

(C) Australasian Plant Pathology Society Inc. 2016

\begin{abstract}
Powdery mildew on soybean was observed in October, 2014. Morphological and molecular characterisation was done for ascertaining the identity of the anamorph. Light and scanning electron microscopy revealed it to be a Pseudoidium anamorph. Morphological characters were examined considering the possibility of presence of Erysiphe glycines, E. diffusa and E. pisi. The shape and dimensions of foot cells and conidia, and wrinkling pattern on conidia were the key features for morphological identification of the pathogen. Molecular identification was done using the Internal Transcribed Spacer (ITS) region of ribosomal DNA and the primer sets ITS5 - ITS4 and ITS1 - PM6. Closely related sequences were included in the maximum likelihood analysis. Morphological and molecular identifications delineate this species as E. diffusa. Accurate pathogen identification is important for disease management and current breeding programs in India.
\end{abstract}

Keywords ITS · Morphology · Glycine max ·

Erysiphe diffusa $\cdot$ E. glycines

India is the fifth largest producer of soybean (Glycine max), behind the USA, Brazil, Argentina and China. Compared to the world average, productivity in India is low (Deosthali et al. 2005). This crop has great potential for enhancing food

Pankaj Baiswar

pbaiswar@yahoo.com

1 ICAR Research Complex for NEH Region, Umiam, Meghalaya 793103, India security of rural households in northeast India. Rust, powdery mildew, stem rot, Rhizoctonia web blight and pod blight are important diseases of soybean in this region causing economic loss.

Powdery mildew symptoms were observed in October 2014 in the reproductive stage of growth (R5) when seeds begin to develop in the pods. The place of collection, ICAR Research Complex for NEH Region, Umiam, Meghalaya, India (Latitude $25^{\circ} 30^{\prime} \mathrm{N}$, Longitude $91^{\circ} 51^{\prime} \mathrm{E}$, elevation $1000 \mathrm{~m}$ ) is situated under mid-hills (Khasi hills). Climate in this region is sub-tropical and humid. The annual precipitation ranges from $1800 \mathrm{~mm}$ to $2500 \mathrm{~mm}$ (Patiram 2003). The pathogens Erysiphe glycines, E. diffusa and E. pisi are known to infect this host (Braun and Cook 2011). Morphological identification of the anamorph is difficult due to many overlaps in characters and therefore molecular characterisation is important for accurate identification of powdery mildews on pulses (Attanayake et al. 2010; McTaggart et al. 2012). In Australia, the pathogen that causes powdery mildew on soybean was identified as E. diffusa using molecular techniques in the absence of teleomorph stage (McTaggart et al. 2012).

Microscopic observations were done using Olympus BX 53 microscope equipped with a digital camera DP 72, Olympus. Specimens were mounted using $3 \%$ potassium hydroxide. Image analysis was done using the Olympus cellSens platform with Standard 1.5 support software. Scanning electron microscopy was also conducted by placing a diseased portion of the leaf on double-sided adhesive transparent tape then sputter-coated with gold under vacuum using Fine Coat Ion Sputter JFC-1100. Gold-coated samples were then placed on aluminium stubs for scanning electron microscopy (SEM) (JEOL JSM 6360, JEOL, Tokyo, Japan). The voucher 


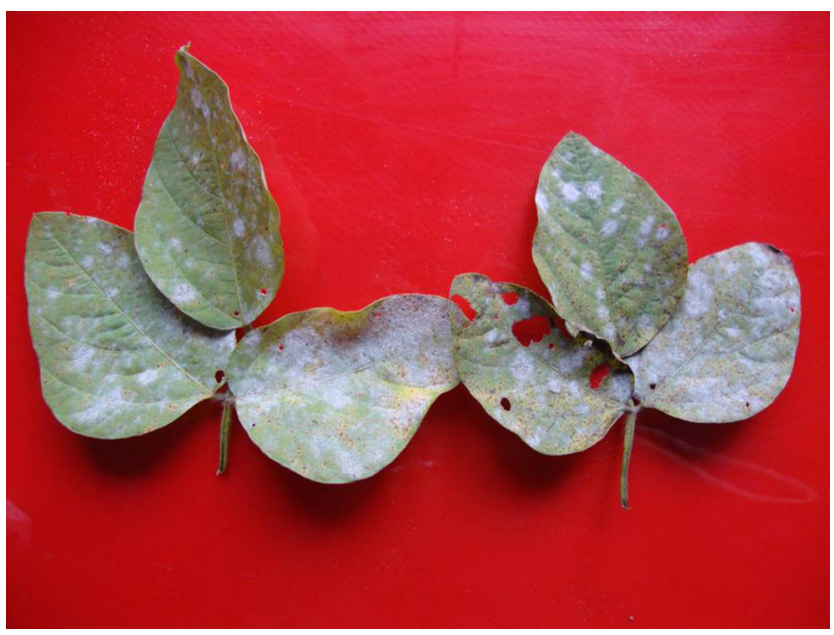

Fig. 1 Powdery mildew symptoms on leaves of soybean

specimen has been deposited at the Agharkar Research Institute Herbarium, Pune, India (AMH- 9764).

DNA extraction was done using the QIAamp DNA Stool Mini Kit (Qiagen). Nested PCR was performed using primer sets ITS 5 - ITS 4 and then ITS 1 - PM 6 (Takamatsu and Kano 2001; White et al. 1990). Cycling conditions were initial denaturation $5 \min \left(94^{\circ} \mathrm{C}\right)$, denaturation $30 \mathrm{~s}\left(94^{\circ} \mathrm{C}\right)$, annealing 30 s $\left(54-52{ }^{\circ} \mathrm{C}\right.$, stepdown approach $-1{ }^{\circ} \mathrm{C}$ in each cycle), extension $40 \mathrm{~s}\left(72{ }^{\circ} \mathrm{C}\right)$ and final extension $5 \min \left(72{ }^{\circ} \mathrm{C}\right)$. Sequencing was done using primers ITS 1 and PM 6.

Phylogenetic analysis was done using two sequences generated in this study (KR131404 and KP242024) and the GenBank reference sequences of powdery mildew species reported on legumes (Takamatsu et al. 2002). Alignment was done using Muscle implemented in MEGA 6.0 (Tamura et al. 2013). Evolutionary model was inferred using jModeltest (Posada 2008). Phylogenetic analysis was done using Maximum likelihood method with Kimura-2parameter model (Bootstrap $=1000$ replicates) as implemented in MEGA 6.0 (Tamura et al. 2013). A discrete Gamma distribution was used to model evolutionary rate differences among sites. Tree optimisation was done using an extensive subtree pruning and regrafting method (SPR-5). The unpublished ITS sequence of E. nishidana (MUMH235) was used as outgroup (kindly provided by Dr. S. Takamatsu).

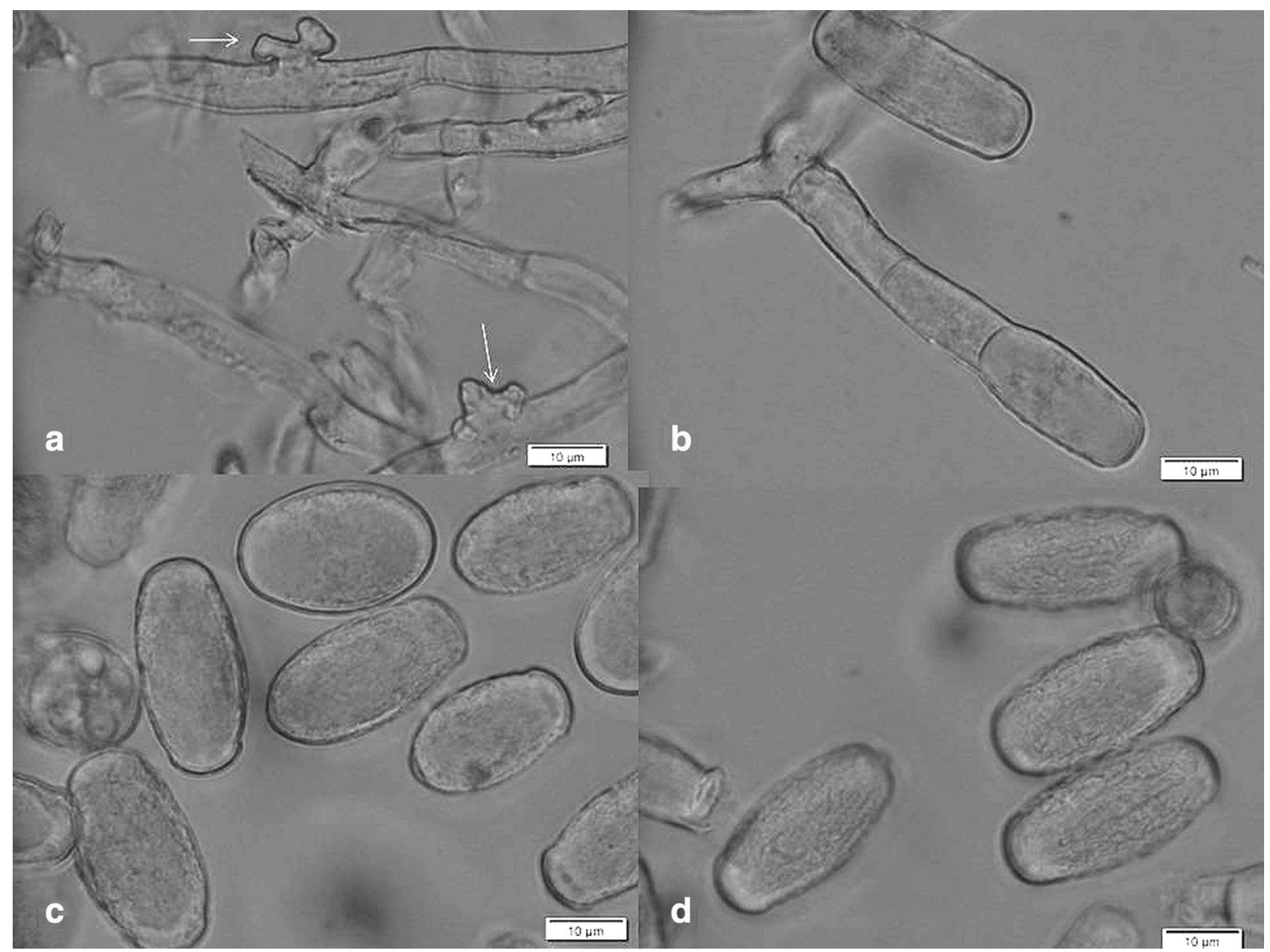

Fig. 2 a Lobed hyphal appressoria of Pseudoidium anamorph b Conidium and conidiophore of Pseudoidium anamorph $\mathbf{c}$ Conidia of Pseudoidium anamorph d Rugose longitudinal wrinkling pattern on conidia of Pseudoidium anamorph 
Fig. 3 a Lobed appressoria on hypahe of Pseudoidium anamorph $($ Bar $=10 \mu \mathrm{m})$ b Longitudinal angular wrinkling pattern on conidia of Pseudoidium anamorph

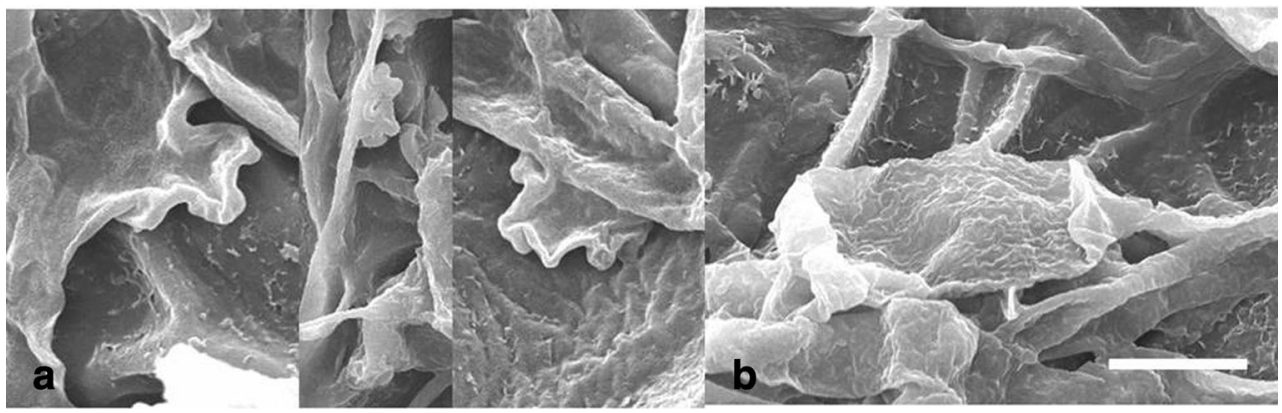

On leaves white powdery growth, circular to irregular, sometimes covering entire leaflets and symptoms were present on both the surfaces but more on upper surface were observed (Fig. 1). Hyphal appressoria were lobed (Figs. 2a and 3a); foot cells were cylindrical, measuring 23-32.5 × 7-9 $\mu \mathrm{m}$; conidia were ellipsoid-cylindrical to doliiform, borne singly (non-catenate), measuring 29-33 × 11-17 $\mu \mathrm{m}$ (Fig. 2b and c); germ tubes were with lobed appressoria; fibrosin bodies were absent. Longitudinal angular wrinkling pattern (considered typical for Pseudoidium anamorphs belonging to Erysiphe) was evident on the surface of the conidia under light microscopy as well as SEM (Figs. 2d and 3b). Morphological descriptions of the anamorphs of the three Erysiphe spp. recorded on soybean (Braun and Cook 2011) were compared with those in our study and shown to fit closely with $E$. diffusa (Table 1). In particular, the foot cells were not flexuous and their smaller size as well as shape and smaller size of conidia indicated that the studied specimen did not belong to $E$. pisi or E. glycines (Table 1). Also, the presence of doliiform conidia did not indicate $E$. pisi.

The consensus sequences have been deposited in GenBank under accession numbers KR131404 and KP242024. Maximum likelihood analysis showed that soybean powdery mildew sequences (KR131404 and KP242024) are closely affiliated with $E$. diffusa sequences (AB078812, AB078813,
FJ378880) and this separation from the remaining species is supported with a high bootstrap value (99\%) (Fig. 4). Consequently, morphological and molecular results indicate that the anamorph of the powdery mildew pathogen on G. max belongs to E. diffusa. Similar findings based on molecular and morphological characterisations of the anamorph were reported for powdery mildew on soybean in Australia (south east Queensland) (McTaggart et al. 2012).

The differentiation amongst E. glycines, E. diffusa and $E$. pisi is usually based on chasmothecia but under tropical conditions these are rare. Anamorph characters can always be used to place a species within the genus Erysiphe sp. on the basis of conidial surface patterns visualised using SEM, conidia borne singly, type of (lobed) appressoria on hyphae and germination pattern (Braun and Cook 2011; Cook and Braun 2009; Cook et al. 1997). Finer details such as shape and dimensions of foot cells and conidia can then be used to distinguish species on a host infected by more than one powdery mildew as in this study.

A few studies have demonstrated that some host resistance genes may be overcome by strains of the morphologically similar pathogen (can be separated on the basis of ITS sequences) in the case of powdery mildews (erl, er2 and Er3 are effective against $E$. pisi but $E$. trifoliorum can overcome erl and Er3) hence the identity of the pathogen is of utmost

Table 1 Anamorphic characters of different Erysiphe sp. on soybean

\begin{tabular}{|c|c|c|c|c|}
\hline \multirow[t]{2}{*}{ Erysiphe sp. } & \multicolumn{2}{|l|}{ Footcells } & \multicolumn{2}{|l|}{ Conidia } \\
\hline & Shape & Dimensions & Dimensions & Shape \\
\hline Erysiphe glycines & $\begin{array}{l}\text { Cylindrical, straight, curved or } \\
\text { somewhat flexuous-sinuous }\end{array}$ & $20-55 \times 6-11(-13) \mu \mathrm{m}$ & $25-50 \times 13-25 \mu \mathrm{m}$ & Ellipsoid-ovoid to doliiform \\
\hline E. diffusa & Cylindrical & $25-38 \times 7.5-10 \mu \mathrm{m}$ & $25-35 \times 11-17.5 \mu \mathrm{m}$ & Ellipsoid-cylindrical (-doliiform) \\
\hline E. pisi & $\begin{array}{l}\text { Subcylindrical, straight or } \\
\text { occasionally flexuous, } \\
\text { curved-sinuous }\end{array}$ & $(15-) 20-50(-70) \times 6-10 \mu \mathrm{m}$ & $25-55 \times(10-) 13-22 \mu \mathrm{m}$ & Ellipsoid-cylindrical \\
\hline $\begin{array}{l}\text { Powdery mildew on } \\
\text { soybean in this study }\end{array}$ & Cylindrical, straight & $23-32.5 \times 7-9 \mu \mathrm{m}$ & $29-33 \times 11-17 \mu \mathrm{m}$ & Ellipsoid-cylindrical to doliiform \\
\hline
\end{tabular}


Fig. 4 Phylogenetic tree inferred using maximum likelihood method and bootstrap values are depicted above the branches

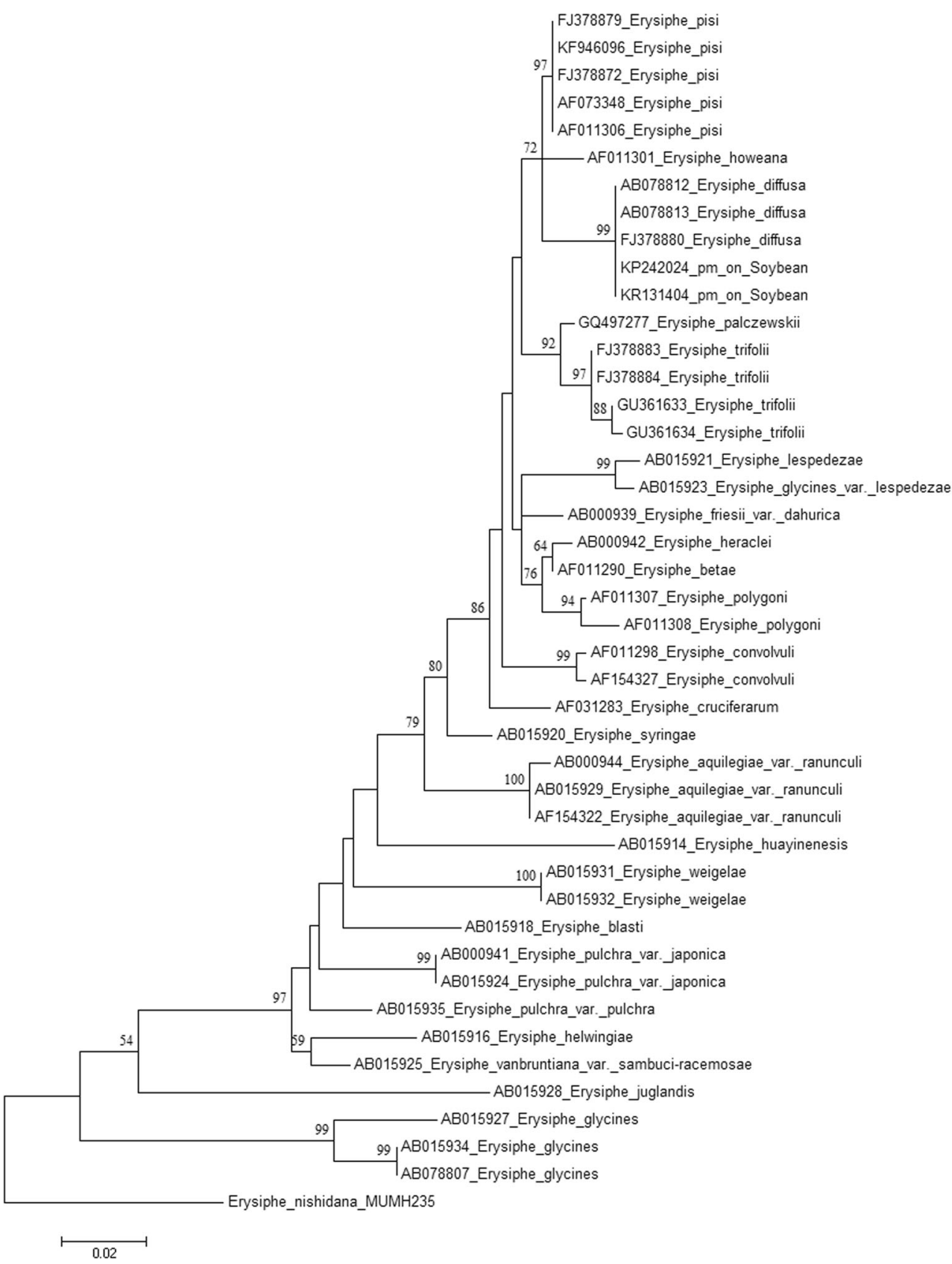

importance for resistance breeding programmes (Fondevilla et al. 2013 and references therein). Accurate pathogen identification is an important first step in breeding as well as management programs.

Acknowledgments This work was done under the Institute project (IXX05432). Authors would like to thank Dr. RTA Cook for presubmission review and suggestions and to Dr. S. Takamatsu for providing unpublished ITS sequence of $E$. nishidana. We would also like to thank the Head, SAIF, Dr. Sudeep Dey (Scientific Officer), Dr. R. Charkraborty, Mr. N. K. Rynjah and Mrs. Clarice R. Thabah for scanning electron microscopy at NEHU, Shillong, Meghalaya, India. Thanks to Animal Production of our Institute for providing facilities for molecular work. The microscope used in this study has been procured under NICRA (PI, Dr. DJ Rajkhowa).
Compliance with ethical standards This article does not contain any studies with human participants or animal.

Conflict of interest The authors declare that they have no conflict of interest.

\section{References}

Attanayake RN, Glawe DA, McPhee KE, Dugan FM, Chen W (2010) Erysiphe trifolii - a newly recognized powdery mildew pathogen of pea. Plant Pathol 59:712-720

Braun U, Cook RTA (2011) Taxonomic manual of the Erysiphales (Powdery Mildews). CBS Biodiversity Series 1, Utrecht, The Netherlands: CBS-KNAW Fungal Biodiversity Centre 
Cook RTA, Braun U (2009) Conidial germination patterns in powdery mildews. Mycol Res 113:616-636

Cook RTA, Inman AJ, Billings C (1997) Identification and classification of powdery mildew anamorphs using light and scanning electron microscopy and host range data. Mycol Res 101:975-1002

Deosthali V, Akmanchi A, Salunke C (2005) Soybean agriculture in India, a spatial analysis. Trans Indian Geogr 27:13-30

Fondevilla S, Chattopadhyay C, Khare N, Rubiales D (2013) Erysiphe trifolii is able to overcome $\operatorname{er} 1$ and $E r 3$, but not er2, resistance genes in pea. Eur J Plant Pathol 136:557-563

McTaggart AR, Ryley MJ, Shivas RG (2012) First report of the powdery mildew Erysiphe diffusa on soybean in Australia. Aust Plant Dis Notes 7:127-129

Patiram (2003) Soil health management for sustainable production. In: Bhatt BP, Bujarbaruah KM, Sharma YP, Patiram (eds) Approaches for increasing agricultural productivity in hill and mountain ecosystem. ICAR Research Complex for NEH Region, Umiam, pp. 15-25
Posada D (2008) jModelTest 0.1 package available at http://darwin.uvigo.es Takamatsu S, Kano Y (2001) PCR primers useful for nucleotide sequencing of rDNA of the powdery mildew fungi. Mycoscience 42:135139

Takamatsu S, Shin HD, Paksiri U, Limkaisang S, Taguchi Y, Binh NT, Sato Y (2002) Two Erysiphe species associated with recent outbreak of soybean powdery mildew: results of molecular phylogenetic analysis based on nuclear rDNA sequences. Mycoscience 43:333-341

Tamura K, Stecher G, Peterson D, Filipski A, Kumar S (2013) MEGA6: molecular evolutionary genetics analysis version 6.0. Mol Biol Evol 30:2725-2729

White TJ, Bruns TD, Lee S, Taylor JW (1990) Amplification and direct sequencing of fungal ribosomal RNA genes for phylogenetics. In: Innis MA, Gelfand DH, Sninsky JJ, White TJ (eds) PCR Protocols: a guide to methods and applications. Academic Press, Inc., San Diego, pp. 315-322 